Original Research Paper

\title{
Unmanned Mini Boat Design for the Camera Bearer of the Vannamei Shrimp Monitoring Device
}

\author{
${ }^{1}$ Bambang Sampurno, ${ }^{2}$ Mashuri, ${ }^{3}$ Arif Abdurrahman, ${ }^{3}$ Herry SufyanHadi, ${ }^{1}$ Suharyanto and ${ }^{1}$ Syamsul Hadi \\ ${ }^{I}$ Department of Industrial Mechanic Engineering, Institut Teknologi Sepuluh Nopember, Surabaya, Indonesia \\ ${ }^{2}$ Department of Engineering Physics, Institut Teknologi Sepuluh Nopember, Surabaya, Indonesia \\ ${ }^{3}$ Department of Instrumentation Engineering, Institut Teknologi Sepuluh Nopember, Surabaya, Indonesia
}

Article history

Received: 03-01-2018

Revised: 19-01-2018

Accepted: 7-03-2018

Corresponding Author:

Bambang Sampurno

Department of Industrial

Mechanic Engineering, Institut

Teknologi Sepuluh Nopember,

Surabaya, Indonesia

Email: bsampurno1965@gmail.com

\begin{abstract}
The research of vanamei shrimp counting has been developed by numerous scientists, but image processing in actual pond didn't progress well. The used of image processing based on the way of capturing the image from the shrimp which located on the bottom of the pond. The way to capture the image was to put a camera under the deck of a boat. Catamaran boat model was selected to build a boat that will bring up a camera that will used to capture shrimp image. The Catamaran boat with Loa (entire length of boat body) $=670 \mathrm{~mm}$, Lenght water line $(\mathrm{Lwl})=650$ $\mathrm{mm}, \mathrm{B}($ width $)=300 \mathrm{~mm}, \mathrm{~T}$ (full/high) $=180 \mathrm{~mm}, \mathrm{Cb}$ (block coefficient $)=$ 0,55 and Vs (speed) $=19$ knots was built to accommodate this matter. The size and specification were chosen to maintain any possibility issue that might happen when the vannamei shrimp monitoring system work.
\end{abstract}

Keywords: Vannamei Shrimp, Camera, Catamaran, Unmanned Boat

\section{Introduction}

A vannamei shrimp monitoring system that uses image processing work principles requires a boat which will bear a camera device in the process of capturing a shrimp object in a pool. Physical parameters such as boat dimensions, electrical conditions, speed, resistance, motion, load carrying ability are important aspects in the building process of unmanned mini boat. These parameters further being utilized to the design of unmanned mini boats to be created as camera carriers in a shrimp monitoring system. To get design accurately worked out, we need to calculate each physical parameter precisely (Anonimous, 2001). This boat design then will be the main part of the vanamei shrimp monitoring system.

\section{Determination of Boat Physical Parameter}

Unmanned mini boat requires several physical parameters that need to be calculated, for instance total boat resistance, boat speed (VS), Volume Displacement, Displacement, Wet Surface Area, Froude Number (Fn), Reynold Number (Rn), Coefficient of Friction Pressure (Cf), Power Efficiency $(\eta \mathrm{H})$, Rotative Relative Efficiency ( $\eta \mathrm{rr})$, Propulsion Efficiency ( $\eta p)$, Resistance Efficiency ( $\eta \mathrm{r})$, Efficiency of Propulsion ( $\eta$ ),
Coefficient of Resistivity (Cr), Coefficient of Air Resistance (Caa), Motor Power Drive, Deliver Horse Power (DHP), Propulsive Coefficient (Pc), Power On Axle Propeller (SHP), Main Movement Power (BHP) (Couser, 2000).

For the calculation of total resistance, GuldhammerHarvald method was used. Physical requirements that is used to calculate resistance of the boat are as follows.

$\begin{array}{ll}\text { Loa (length of the boat entire body) } & =670 \mathrm{~mm} \\ \text { Lwl (Lenght water line) } & =650 \mathrm{~mm} \\ \mathrm{~B} \text { (widht) } & =360 \mathrm{~mm} \\ \mathrm{~T} \text { (high) } & =180 \mathrm{~mm} \\ \text { Cb (Block Coefficient) } & =0,327 \\ \text { Vs (boat speed) } & =19 \mathrm{knot}\end{array}$

The coefficient of boat total resistance or $\mathrm{Ct}$, can be determined by summing up all existing boat resistance coefficients.

The total resistance (RT) on the boat consists of components that play role in creating a drag. In principle, there are two parts of the boat that experience the drag force - the area of the boat's sinking and the area of the boat on the surface of the water because the air also has a resistivity factor under certain conditions (Bhattacaryya, 1978). RT is used to determine the size of the Effective Horse Power (EHP) which is defined as the power 
required for a boat to move at a speed of VS and able to overcome the resistance force of the RT and more importantly to find out how much power from the main engine to the boat to be made not experience the excessive power or just cannot meet the speed because the predicted power cannot overcome the boat's resistance (Harvald, 1983).

Volume Displacement is the volume of water removed and is one of the important variables in the calculation of boat resistance. Volume of the body of the boat below the surface of the water but not including the thickness of the skin, the thickness of the keel, the thickness of the steering wheel, propeller and all the water-immersed boats (Parsons, 2003):

$$
V=L w l \times B \times T \times C b
$$

Where:

$$
\begin{array}{ll}
V & =\text { Volume }\left(\mathrm{m}^{3}\right) \\
B & =\text { boat width }(\mathrm{m}) \\
T & =\text { Height of boat }(\mathrm{m}) \\
C b & =\text { Coefficient block }
\end{array}
$$

In this research, the value of $V$ is, $019305 \mathrm{~m}^{3}$.

Weight Displacement is the weight of water transferred by the volume of the dyed boat:

$$
\Delta=L w l \times B \times T \times C b \times \rho
$$

where, $\rho=$ sea water density $\left(1.025 \mathrm{ton} / \mathrm{m}^{3}\right)$

In this research, $D$ value is $19,3 \mathrm{~kg}$.

The wet surface area is the surface area of the water dusted hull. Wet surfaces for normal commercial boats can be calculated using the following formula:

$$
S=\rho \times \operatorname{Lwl}(C b \times B)+(1,2 \times T)
$$

where, $\rho=$ water density $\left(1000 \mathrm{~kg} / \mathrm{m}^{3}\right)$.

In this research, $S$ value is $0,24765 \mathrm{~m}^{2}$, with ratio of $\mathrm{B} / \mathrm{T}=1,667$ :

$$
F n=V s / \sqrt{g} \times L w l
$$

Where:

$$
\begin{array}{ll}
V_{S} & =\text { Speed of boat }(\mathrm{knot}) \\
1 \mathrm{knot} & =0,554 \mathrm{~m} / \mathrm{s} \\
g & =\text { Gravity acceleration }\left(9,8 \mathrm{~m} / \mathrm{s}^{2}\right)
\end{array}
$$

In this research, $F n$ value is 11,686 :

$$
R n=(V s \times L w l) / v
$$

Where:

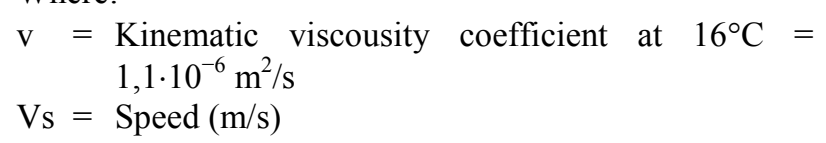

In this research, $R n$ value is 3.300 .000 :

$$
C f=0.075(\log R n-2)^{2}
$$

In this research, $C f$ value is 0,0017 .

The coefficient of the remaining boat resistance can be determined through the diagram (GuldhammerHarvald) with the result is as follows:

$$
C r=L w l / \nabla^{1 / 3}
$$

Where:

$$
\begin{aligned}
\nabla & =\text { Boat volume }\left(\mathrm{m}^{3}\right) \\
F n & =11,686 \\
C b & =0,55
\end{aligned}
$$

If the diagram is based on the width ratio of $\mathrm{B} / \mathrm{T}=$ 2.5 then the $\mathrm{Cr}$ price for a boat having a width-laden ratio greater or less than that price must be corrected:

$$
\begin{aligned}
& \mathrm{B} / \mathrm{T}=1,67 \\
& 10^{3} \mathrm{CR}=10^{3} \mathrm{CR}(\mathrm{B} / \mathrm{T}=2.5)+0.16(\mathrm{~B} / \mathrm{T}-2.5) \\
& 10^{3} \mathrm{CR}=10^{3} \mathrm{CR}(\mathrm{B} / \mathrm{T}=2.5)+0.16(1,67-2.5) \\
& C r=0,01328
\end{aligned}
$$

From the $C r$ value we can assume that:

$$
\begin{aligned}
& C r \text { total }=\left(1,8 \cdot 10^{-3}\right)+0,01328 \\
& =0,015
\end{aligned}
$$

Since the data on wind in boat design is unknown, it is recommended to correct the coefficient of air resistance, where the value is:

$$
C a a=0,00007
$$

The boat's resistance is the drag force of the fluid medium through which the boat operates at a certain speed (Harvald, 1983). The magnitude of this total inhibitory force is the sum of all components of the inhibitory force (obstacle) (Guldhammer, 1962). In simple terms the total boat resistance can be obtained by the equation, as follows:

$$
C T \text { Total }=C f+C r+C a a
$$

So the total resistance (RT) by entering the total CT:

$$
R T=0,5 \times \rho \times C T \times S \times V s^{2}
$$

where, $s$ is the wet surface area of the boat $\left(\mathrm{m}^{2}\right)$. Table 1 describe the Guldhammer-Harvald equation with different $\mathrm{Cr}$. 
Table 1: Guldhammer-Harvald $\mathrm{Cr}$ coefficient

\begin{tabular}{ll}
\hline $\mathrm{A}$ & $\mathrm{B}$ \\
\hline 1. $\mathrm{L} / \nabla^{1 / 3}=2,0$ & $\mathrm{Cr}=1,5 \times 10^{-3}$ \\
2. $\mathrm{L} / \nabla^{1 / 3}=2,4$ & $\mathrm{Cr}=\mathrm{x}$ \\
3. $\mathrm{L} / \nabla^{1 / 3}=2,5$ & $\mathrm{Cr}=1,2 \times 10^{-3}$ \\
\hline
\end{tabular}

In this research, we use $R T$ value of $0,0785 \mathrm{kN}$. As a result of the boat's resistance, there must be a thrust of the boat used to overcome the boat drag force. Under ideal conditions, the amount of required thrust is as large as the inhibitory force on the boat. However, the condition is not very realistic, because in fact in the boat body occurs hydrodynamic phenomenon that cause degradation of the value of the thrust force (Eyres, 2001).

\section{Calculation of Boat's Motor Power}

From the figure above, it is explained that the RT is the total resistance of a boat that can inhibit the velocity (Vs) of the boat. To drive the boat with the desired speed required motor power (Lewis, 1988). While the motor power there are two types of continuous power and maximum power. Continuous power to achieve service speed and maximum power to achieve maximum speed or trial speed.

There are several terms of horse power as a known motor power in the boat that is IHP, BHP, SHP or DHP or PHP and EHP. EHP is determined from the pressure inside the cylinder or taken into account from the motor diagram. $\mathrm{BHP}$ is the power required to rotate the shaft and its value is less than the IHP due to the loss of power inside the cylinder. SHP is determined from torque on the shaft and EHP is the power required to drive the boat (Insel, 1992).

Effective Horse Power (EHP) is the amount of power required to overcome the drag force of the boat body (hull), so that the boat can move from one place to another with a service speed of Vs:

$$
E H P=R t \times V S
$$

Where:

$1 \mathrm{HP}=745.699$ watt

$1 \mathrm{KW}=0,7335 \mathrm{HP}$

In this research, EHP value is 0,355 HP.

Delivery Horse Power (DHP) is the power absorbed by the boat's propellers to generate the Push Power, or in other words DHP is the power that is propagated by the propulsion motor to the propeller which is then converted into a thrust force. Power on the propeller shaft tube or DHP is calculated from the comparison between Effective Power or EHP with Propulsive Coefficients or PC:

$$
D H P=E H P / P C
$$

Where:

$P C=\eta p \cdot \eta r r \cdot \eta \mathrm{H}$

$\eta \mathrm{H}=(1-\mathrm{t}) /(1-\mathrm{w})$

Wake friction (w) or current join is a comparison between the speed of the boat with the speed of water leading to the propeller. By using the formula given by Taylor then obtained:

$$
w=0.5 C b-0.05
$$

In this research, $w$ value is 0,255 .

The value of thrust deduction factor $(t)$ can be sought from the known value of $w$ :

$$
t=k \times w
$$

The $k$ value is between $0.7-0.9$ and the value of $k=$ 0.8 is taken so that $\mathrm{t}$ is 0.18 :

$$
\eta H=(1-t) /(1-w)=1,1
$$

Price $\eta r r$ for boat with single screw type propeller ranges from 1.0-1.1. In the propeller planning and propeller shaft tube is taken price:

$$
\eta r r=1.05
$$

The efficiency of propulation is open water efficiency which is the efficiency of the propeller at the time of open water test. The value between $40-70 \%$ and $60 \%$ were taken (Molland, 2008).

From the various explanations, the $\mathrm{PC}$ value is 0.693 and DHP is $0.512 \mathrm{HP}$. Shaft Horse Power (SHP) is the measured power up to the area in front of the shaft tube bearings (stern tube) of the boat propulsion system. Here the boat has engine room at the back, with loss (2-3)\%, taken $2 \%$. So that the efficiency of the bearing and the propeller tube or $\eta \mathrm{S} \eta \mathrm{B}$ is 0.98 :

$$
S H P=D H P / \eta s \eta b
$$

In this research, SHP value is 0,522 HP.

Brake Horse Power (BHP) is the brake power (Brake Power) or power received by the boat propulsion system shaft, which is then operated continuously to drive the boat at its service speed (Vs). The magnitude of the main driving force or $\mathrm{PB}$ required in the planning of the propeller vanes and tubes is not detached by the efficiency of the gear and transmission system or $\eta \mathrm{G}$ because it is planned on the connection of the power transmission system between the motor with the propeller shaft mounted wheel system tooth reduction. The gear system on this boat uses a single reduction gear or single reduction gear with $2 \%$ loss. For forward and reverse gear or Reversing Gear with $1 \%$ loss. 


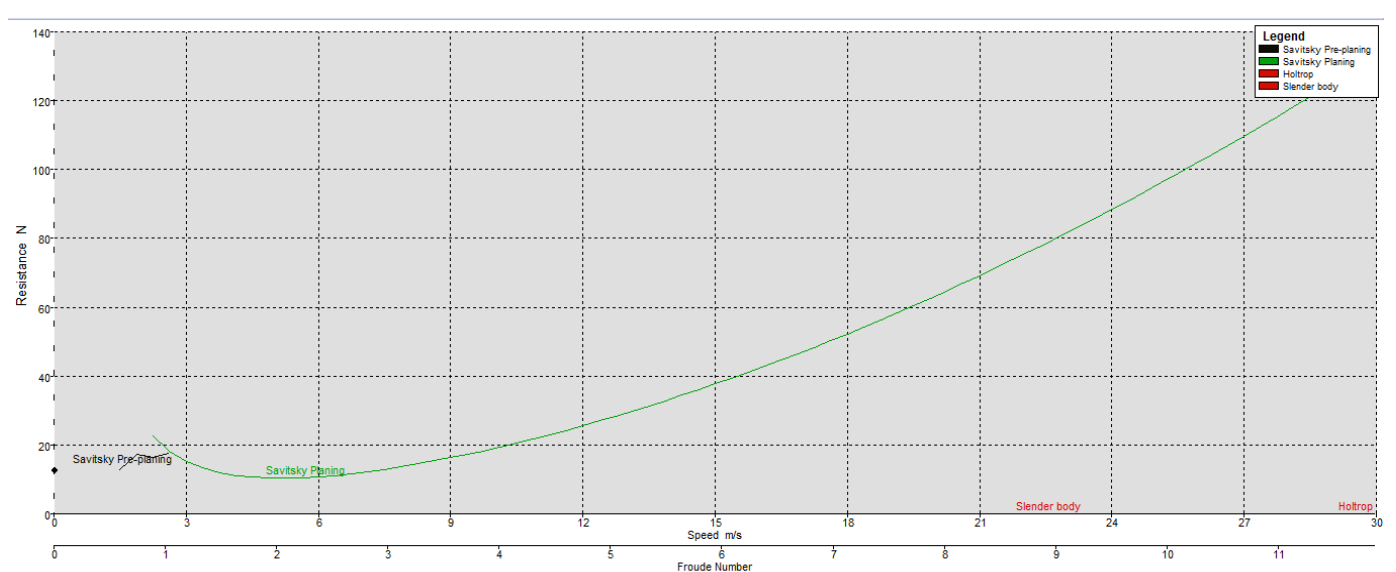

Fig. 1: Resistance Vs Speed

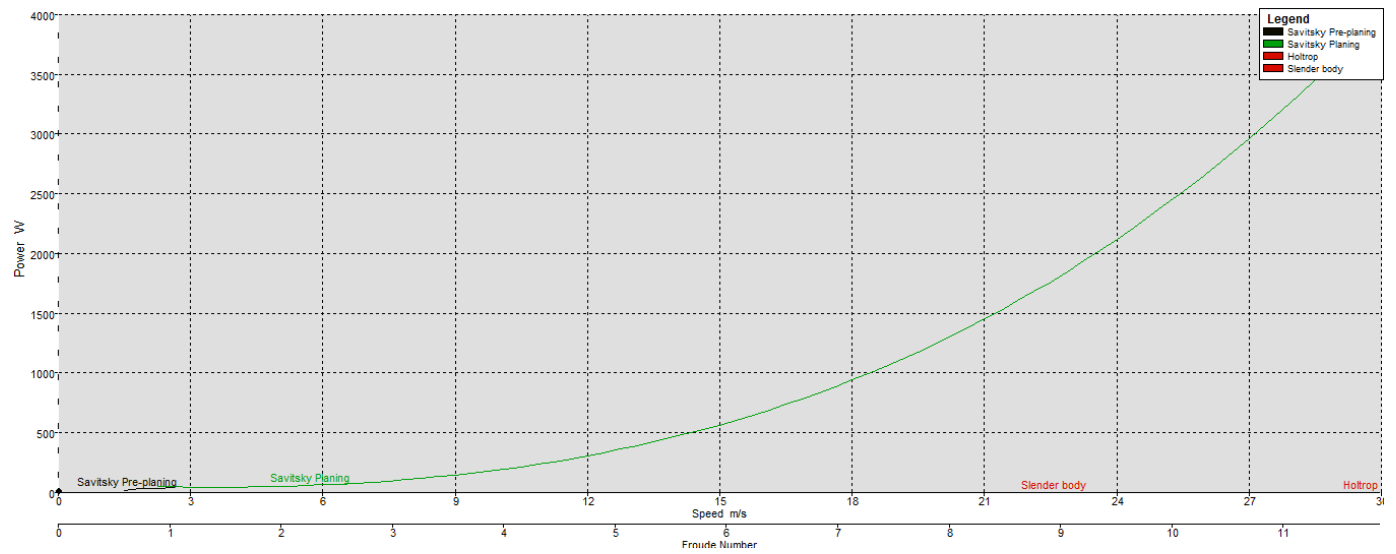

Fig. 2: Power Vs Speed

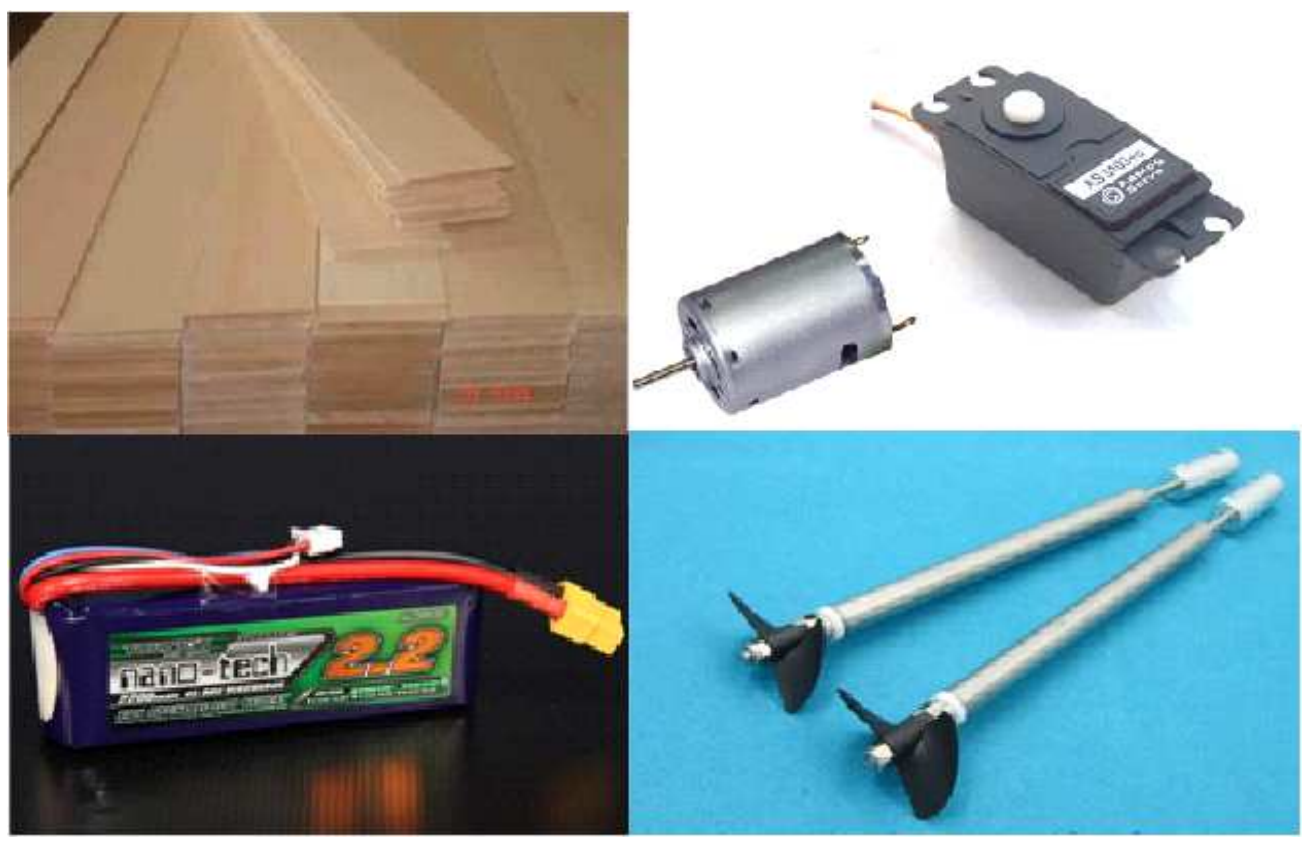

Fig. 3: Miniboat components 
From the data of this system can know the efficiency of transmission gear system or $\eta \mathrm{g}$ of each system is:

- $\eta \mathrm{g}=98 \%$ single reduction gears

- $\eta \mathrm{g}=99 \%$ reversing reduction gears

BHP (scr) is the output power of the surge motor under conditions (Continues Service Rating). Taking the value $\eta \mathrm{g}=0.98$ :

$$
\text { BHPscr }=S H P / \eta g
$$

In this research, BHPscr value is 0,533 HP.

The magnitude of the power of this prime motor or motor is the output power on a normal voyage or SCR, where the magnitude is $80-85 \%$ of the output power at maximum or MCR. While the output power at MCR condition is:

$$
\text { BHPmcr }=\text { BHPscr } / 0.85
$$

In this research, BHPmcr value is $0,4599 H P$.

BHP (mcr) is then used as a benchmark (reference) in implementing the Engine Selection Process.

\section{Calculation of Boat Resistance}

The calculation of the resistance experienced by the boat is obtained directly from the maxsurf software. In this study, the savitsky, slender body and holtrop method is used because the type of boat that is designed is the displacement hull type where the calculation of the resistance can only be done by using the method (Siswanto, 1988). The following calculations obtained by using software maxsurf.

The following is the resulting resistance graph with the hullspeed feature on the Maxsurf Software and the Speed Power Prediction graph.

\section{Manufacturing Process}

The design of unmanned mini boats used some components such as balsa wood, brushless motor, servo motors, batteries and propeller (Santosa, 1999). Selection of these components was considered being the design and specifications that has been usually used for shrimp monitoring. Balsa wood was chosen because of its material characteristics of which the fibers orientation within the woods make it easier to be shaped and hence the body of the boat can be manufactured without taking to much time and effort (Rahman, 1998). Brushless motor (Bldc motor) which is one of motor type was selected according to the magnitude of the boat's power. This motor is used to convert electrical energy into motion energy and hence drives the propeller. Synchronous motor means that the magnetic field generated by the rotor rotates at the same frequency so that the bldc motor does not slip as it may commonly happen in the induction motors. This type of motor has a permanent magnet on the rotor and electromagnet in the stator. Bldc motors used have specifications:

$\begin{array}{ll}\text { Type: } & \text { D3536 } \\ \text { Max Power: } & 500 \mathrm{~W} \\ \text { Sfoc: } & 186 \\ \text { Machine Dimention Dimensions: } & 35 \cdot 36 \mathrm{~mm} \\ \text { Diameter of shaft: } & 5 \mathrm{~mm} \\ \text { Battery: } & 7,4-14 \mathrm{~V} \\ \text { RPM (max): } & 1250 \mathrm{kv} \\ \text { Rotation: } & 1250 \mathrm{kv} \cdot 8 \mathrm{v} \\ & 8750 \mathrm{rpm}(\max ) \\ \text { Engine Weight (Net Dry): } & 102 \mathrm{~g}\end{array}$

The next step, $180^{\circ} \mathrm{C}$ servo motor is selected as needed to turn right and left by moving the rudder. Servo motor is a device or rotary actuator (motor) designed with a closed-loop feedback control system (servo), so it can be set-up or set to determine and ensure the angular position of the motor output shaft (Stish Kumar et al., 2000). Servo is a DC motor equipped with a control circuit with closed feedback system integrated in the motor. In the motor servo, the position of the axis rotation of the motor will be informed back to the control circuit inside the servo motor. The motor servo is composed of a DC motor, gearbox, Variable Resistor (VR) or potentiometer and control circuit. Potentiometer serves to determine the maximum limit of axis rotation (axis) servo motor. While the angle of the servo motor axis is set based on the width of the pulse on the servo motor control pin (Prawitasari, 2013). Power source used in this mini boat is battery powered $22000 \mathrm{mAh}, 3 \mathrm{~S} 1 \mathrm{P} / 3$ voltage Cell/11.1V, weight $187 \mathrm{~g}$, dimension $106 \cdot 35 \cdot 24$ $\mathrm{mm}$ with endurance $8 \mathrm{~h}$ usage. In this mini boat, propeller is chosen with which match to the diameter of the propeller shaft. Propeller Shaft (Propeller Shaft) is one part of power transfer system where the distance between Bldc motor and propeller is far apart. Furthermore, propeller shafts will be connected with boat propellers. Propeller is a tool for producing the most widely used thrust force of propellers rotated with a propeller shaft powered by a Bldc motor.

Furthermore mini boats are designed with Marxsurfsoftware based on previous parameters on boat calculations. Once entered maxsurf software will appear the calculation of the speed of the boat, the maximum load is transported boat and hydrostatic calculation automatically. The output of this software is also in the form of cross-sectional design which is then used as part of the boat as Fig. 4. Balsa wood is formed according to the mold to be captured into a boat body such as Fig. 5 . After all parts of the boat is assembled in the market of various components that have been selected previously. The next stage in the design of mini boats is to test the work of mini boats in ponds such as Fig. 6 . 


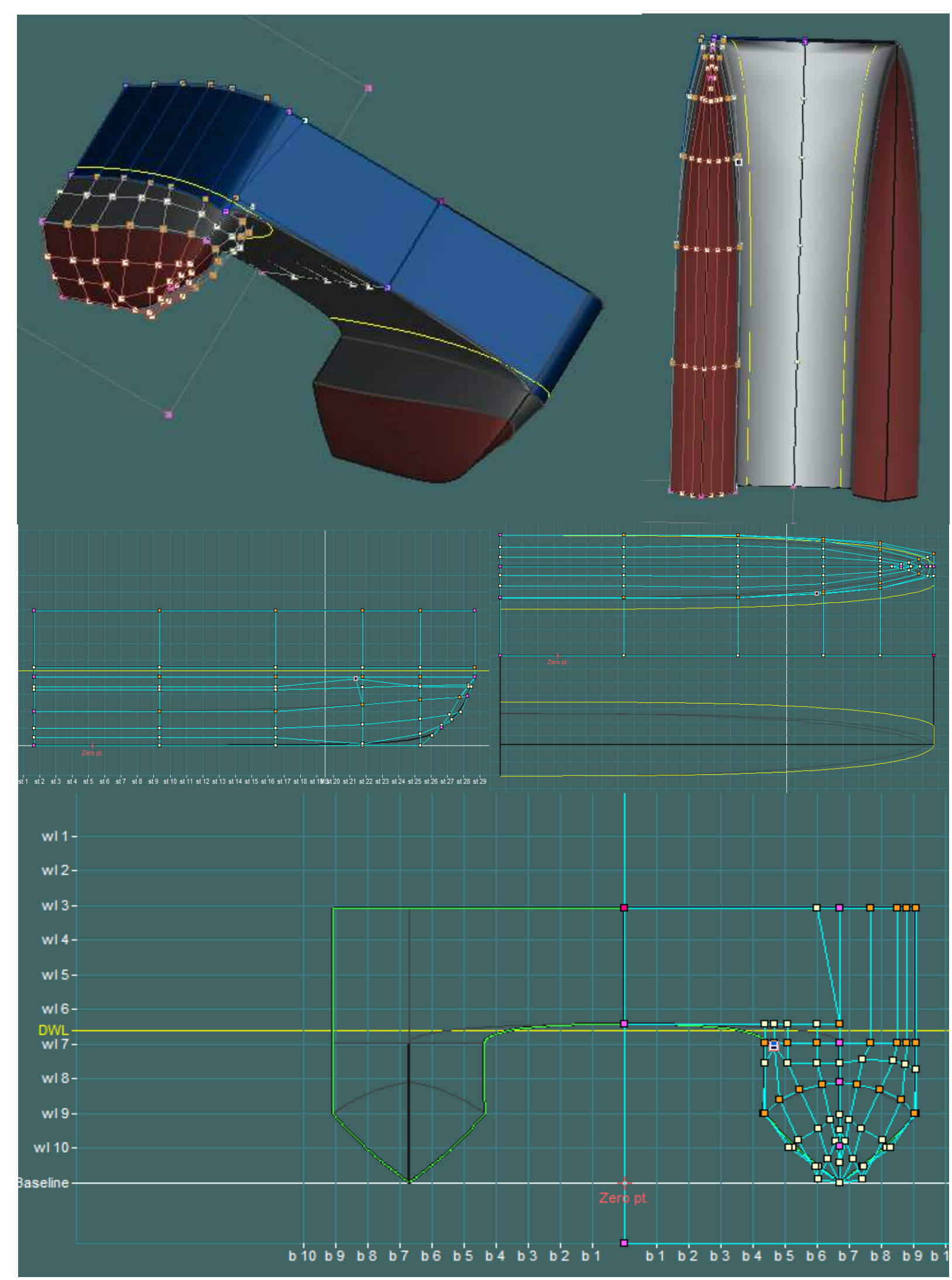

Fig. 4: Boat design 


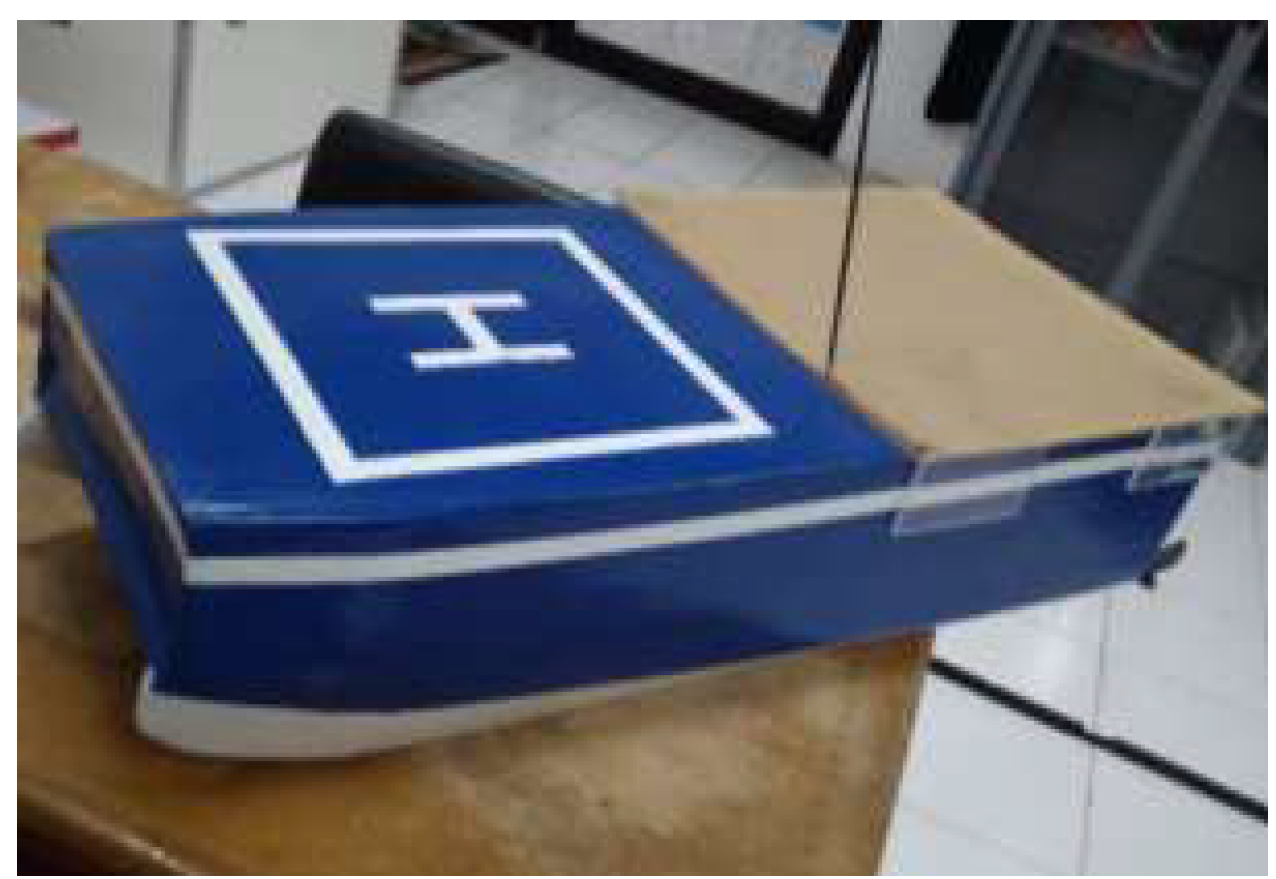

Fig. 5: Unmanned mini boat

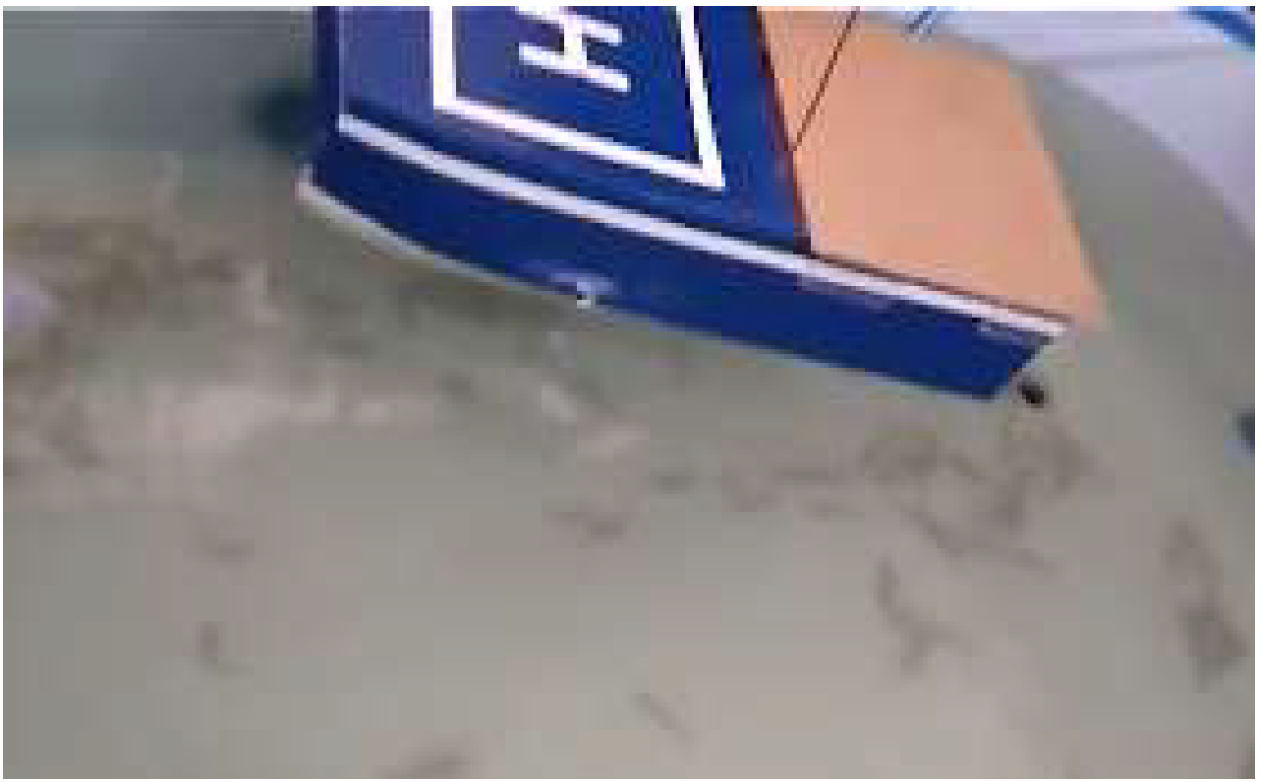

Fig. 6: Mini boat Trial

Based on Table 2 obtained from ship stability analysis using Marxsurf software, it can be seen that the ship displacement value is 7,835 meaning that the maximum load able to lift the ship is $7,835 \mathrm{~kg}$ with displacement volume of $7643,96 \mathrm{~cm}^{3}$ according to its manual calculation. In Table 2 it is also found that the draft on Fp, $\mathrm{AP}$ and LCF is the same value of $10 \mathrm{~cm}$, meaning that the design of the ship is at an ideal equilibrium point (Santoso and Sudjono, 1983). In other hydrostatic analysis parameters show the same thing, ship design is ideal condition as needed in carrying equipment of monitoring tool of shrimp in the form of camera and others.

Furthermore, in Table 3, the simulation of the stability of the ship's design on the condition of the ship is exposed to water waves that can cause the ship to overturn. It is seen that there is a change of GZ, $\mathrm{Cp}$ and $\mathrm{Cb}$ values (Watson, 1998). This change indicates that on the slope of the ship 0 to 20 degrees the ship is potentially skewed. 
Table 2: Hydrostatic Analysist

\begin{tabular}{|c|c|}
\hline Displacement kg & 7.835 \\
\hline Volume (displaced) $\mathrm{cm}^{3}$ & 7643.960 \\
\hline Heel deg & 0.000 \\
\hline Draft at FP $\mathrm{cm}$ & 10.000 \\
\hline Draft at AP cm & 10.000 \\
\hline Draft at LCF cm & 10.000 \\
\hline Trim (+ve by stern) $\mathrm{cm}$ & 0.000 \\
\hline WL Length $\mathrm{cm}$ & 65.000 \\
\hline Max sect. area $\mathrm{cm}^{2}$ & 149.100 \\
\hline Sect. area amidships $\mathrm{cm}^{2}$ & 117.110 \\
\hline Wetted Area $\mathrm{cm}^{2}$ & 3025.380 \\
\hline Waterpl. Area $\mathrm{cm}^{2}$ & 1270.420 \\
\hline Prismatic coeff. $(\mathrm{Cp})$ & 0.789 \\
\hline Block coeff. $(\mathrm{Cb})$ & 0.327 \\
\hline Max Sect. area coeff. $(\mathrm{Cm})$ & 0.675 \\
\hline Waterpl. areacoeff. (Cwp) & 0.544 \\
\hline LCB from zero pt. $(+v e f w d) \mathrm{cm}$ & 18.380 \\
\hline LCF from zero pt. (+vefwd) $\mathrm{cm}$ & 21.100 \\
\hline $\mathrm{KB} \mathrm{cm}$ & 6.090 \\
\hline $\mathrm{KG} \mathrm{cm}$ & 10.000 \\
\hline $\mathrm{BMt} \mathrm{cm}$ & 27.100 \\
\hline $\mathrm{BML} \mathrm{cm}$ & 52.770 \\
\hline GMt cm & 23.190 \\
\hline GML cm & 48.870 \\
\hline $\mathrm{KMt} \mathrm{cm}$ & 33.190 \\
\hline $\mathrm{KML} \mathrm{cm}$ & 58.870 \\
\hline Immersion $(\mathrm{TPc})$ tonne/cm & 0.001 \\
\hline MTctonne.m & 0.000 \\
\hline $\mathrm{RM}$ at $1 \mathrm{deg}=\mathrm{GMt} \cdot$ Disp.sin(1) kg.cm & 3.170 \\
\hline Max deck inclination deg & 0.000 \\
\hline Trim angle (+ve by stern) deg & 0.000 \\
\hline Density of Seawater $\mathrm{kg} / \mathrm{cm}^{3}$ & 1000.000 \\
\hline
\end{tabular}

But above 20 degrees the value of the parameter is decreased, which means the ship will never have a slope of more than 20 degrees. This indicates that the vessel has excellent stability until it cannot be reversed if operated in a pond while loading a monitoring tool of shrimp counts.

Figures 1 and 2 illustrate the ship's performance analysis by comparing the speed with which the vessel can attain resistance and the required power. In this analysis used four methods in analyzing the Holtrop method, Slender body method, and Savitsky method both pre-planning and planning (Seif and Amini, 2004). In Figure 1 showing the relationship between resistance and velocity, it is shown that the right method is Savitsky. It appears that in the initial simulation the vessel was moving at a speed of about $2 \mathrm{~m} / \mathrm{s}$ of ship resistance in the range of $20 \mathrm{~N}$, the initial turbulence of the vessel made a major obstacle. However, when the speed increases to $6 \mathrm{~m} / \mathrm{s}$ resistance decrease, and increases again as speed increases.

Figure 2 shows the relationship between speed and the required driving force. As in the analysis of the relationship speed and resistance, the appropriate method of analyzing is Savitsky. This is because Savitsky methods are more sensitive to small-sized ship designs, while other methods are more sensitive to large vessels (Dubrovsky et al., 2001). In Figure 2 it appears that the driving power requirement is proportional to the increase in speed of the speeding vessel. Figure 3 shows the ship's components corresponding to the ship's performance requirements according to the design and analysis of the stability and performance of the vessel. Figure 4 shows the design of the ship in the form of 3-dimensional design as well as seen from the top, side and front.

Table 3: Heel to Starboard Simulation

\begin{tabular}{|c|c|c|c|c|c|c|c|c|c|c|c|}
\hline Heel to Starboard De & -50 & -40 & -30 & -20 & -10 & 0 & 10 & 20 & 30 & 40 & 50 \\
\hline $\mathrm{GZ} \mathrm{m}$ & -0.0710 & -0.0880 & -0.104 & -0.1160 & -0.0710 & 0 & 0.0710 & 0.1160 & 0.1040 & 0.0880 & 0.0710 \\
\hline $\begin{array}{l}\text { Area under GZ curve from } \\
\text { zero heel m.deg }\end{array}$ & 4.2106 & 3.4140 & 2.4609 & 1.3351 & 0.3601 & 0 & 0.3601 & 1.3351 & 2.4609 & 3.4140 & 4.2105 \\
\hline Displacement kg & 3.9500 & 3.9500 & 3.9500 & 3.9500 & 3.9500 & 3.9500 & 3.9500 & 3.9500 & 3.9500 & 3.9500 & 3.9500 \\
\hline Draft at FP m & -0.0410 & 0.0070 & 0.0420 & 0.0680 & 0.0790 & 0.0820 & 0.0790 & 0.0680 & 0.0420 & 0.0070 & -0.0410 \\
\hline Draft at AP m & -0.0720 & -0.0250 & 0.0100 & 0.0390 & 0.0490 & 0.0480 & 0.0490 & 0.0390 & 0.0100 & -0.0250 & -0.0720 \\
\hline WL Length $\mathrm{m}$ & 0.6500 & 0.6500 & 0.6500 & 0.6500 & 0.6500 & 0.6440 & 0.6500 & 0.6500 & 0.6500 & 0.6500 & 0.6500 \\
\hline Beam max extents on WL $\mathrm{m}$ & 0.1560 & 0.1610 & 0.1680 & 0.3350 & 0.3510 & 0.3600 & 0.3510 & 0.3350 & 0.1680 & 0.1610 & 0.1560 \\
\hline Wetted Area $\mathrm{m}^{\wedge} 2$ & 0.1470 & 0.1460 & 0.1450 & 0.1510 & 0.1860 & 0.1970 & 0.1860 & 0.1510 & 0.1450 & 0.1460 & 0.1470 \\
\hline Waterpl. Area $\mathrm{m}^{\wedge} 2$ & 0.0780 & 0.0670 & 0.0600 & 0.0610 & 0.0920 & 0.0990 & 0.0920 & 0.0610 & 0.0600 & 0.0670 & 0.0780 \\
\hline Prismatic coeff. (Cp) & 0.8340 & 0.8330 & 0.8330 & 0.8330 & 0.8080 & 0.8050 & 0.8080 & 0.8330 & 0.8330 & 0.8330 & 0.8340 \\
\hline Block coeff. $(\mathrm{Cb})$ & 0.6070 & 0.6040 & 0.6040 & 0.5520 & 0.3930 & 0.4710 & 0.3930 & 0.5520 & 0.6040 & 0.6040 & 0.6070 \\
\hline LCB from zero pt. (+vefwd) m & 0.2840 & 0.2850 & 0.2850 & 0.2840 & 0.2840 & 0.2840 & 0.2840 & 0.2840 & 0.2850 & 0.2850 & 0.2840 \\
\hline LCF from zero pt. (+vefwd) m & 0.2890 & 0.2890 & 0.2920 & 0.3040 & 0.2820 & 0.2790 & 0.2820 & 0.3040 & 0.2920 & 0.2890 & 0.2890 \\
\hline Max deck inclination deg & 50.0107 & 40.0236 & 30.0435 & 20.0662 & 10.1631 & 2.0754 & 10.1632 & 20.0664 & 30.0433 & 40.0234 & 50.0107 \\
\hline $\begin{array}{l}\text { Trim angle } \\
(+ \text { ve by stern) deg }\end{array}$ & -1.8839 & -1.9658 & -1.9589 & -1.7696 & -1.8509 & -2.0754 & -1.8515 & -1.7720 & -1.9551 & -1.9571 & -1.8762 \\
\hline
\end{tabular}




\section{Conclusion}

The Catamaran boat with Loa (entire length of boat body $)=670 \mathrm{~mm}$, Lenght water line $(\mathrm{Lwl})=650 \mathrm{~mm}, \mathrm{~B}$ (width) $=300 \mathrm{~mm}, \mathrm{~T}$ (full $/$ high) $=180 \mathrm{~mm}, \mathrm{Cb}$ (block coefficient) $=0,55$ and Vs (speed) $=19$ knots was built to bear camera that used for vannamei shrimp monitoring system.

\section{Acknowledgement}

This research was supported by Institut Teknologi Sepuluh Nopember. We thank our colleagues from Naval architecture department, Instrumentation department and engineering physics department who provided insight and expertise that greatly assisted the research, although they may not agree with all of the conclusions of this paper.

\section{Funding Information}

This research was funded by Institut Teknologi Sepuluh Nopember by 'Penelitian Pengembangan Prototype Dana Lokal ITS 2017' program and our research partner PT Pyramide Paramount Indonesia.

\section{Author's Contributions}

Bambang Sampurno: Chief of research team, most contribution in research idea, partnership, team management, resources support.

Mashuri: Assistance and secretary of research team, support the needs of research activity, prepare the requirement of the research activity.

Arif Abdurrahman: Programmer of the research team.

Herry SufyanHadi: Manufacturer of the research team.

Suhariyanto: Property manager of the research.

Syamsul Hadi: Vice chief of research team, advice the progress of the research activity.

\section{Ethics}

Authors should address any ethical issues that may arise after the publication of this manuscript.

\section{References}

Anonimous, 2001. Rules for Hull Biro Klasifikasi Indonesia Vol. II, Edition 2001.

Bhattacaryya, R., 1978. Dynamics Of Marine Vehicles. New York: John Wille y \& Sons Inc.

Couser, P., 2000. Seakeeping Analysis for Preliminary Design. Ausmarine.

Dubrovsky, V. and A. Lyakhovitsky, 2001. Multi-Hull Ships. USA: Blackbone Publishing Company.
Eyres, D.J., 2001. Ship Construction. Oxford: Butterworth-Heineimann.

Guldhammer, H.E., 1962. FORMDATA Some Systematically Varied Ship Forms and their Hydrostatic Data, Danish Technical Press, Copenhagen, Denmark.

Harvald, S.A., 1983. Resistance and Propulsion of Ships, John Wiley and Sons, Toronto, Canada.

Insel, M. and A.F. Molland, 1992. An Investigation Into the Resistance Components of High Speed Displacement Catamaran. The Royal Institution of Naval architects.

Lewis, E.V., 1988. Principles of Naval Architecture Second Revision. The Society of Naval Architecture and Marine Engineers, Jersey, NJ, USA.

Molland, A.F., 2008. A Guide to Ship Design, COnstruction and Operation. The Maritime Engineering Reference Book, ButterworthHeinemann, Elsevier.

Parsons, M.G., 2003. Ship Design and Construction Volume II. Jersey City: The Society of Naval Architect and Marine Engineering.

Prawitasari, N., 2013. Makalahmesinmesinlistrikpenggunaan motor servo Pada robot. STT-PLN. Jakarta.

Rahman, M.K., 1998. Ultimate Strengh Estimation of Ship's Transverse Frames by Incremental ElasticPlastic Finite Element Analisys. Newcastle: University of Newcastle Upon Tyne.

Santoso, I.G.M. and Y.J. Sudjono, 1983. "Teori Bangunan Kapal“. Direktorat Pendidikan Menengah Kejuruan, Departemen Pendidikandan Kebudayaan, Indonesia.

Santosa, I.G.M., 1999. Diktat Kuliah Perencanaan Kapal. ITS Surabaya.

Seif, M.S. and E. Amini, 2004. Performance Comparison between Planning Monohull and Catamaran at high Froud Number. Iranian J. Sci. Technology, Transaction B.

Siswanto, D., 1988. Teori Tahanan Kapal I“ Fakultas Teknologi Kelautan, Institut Teknologi 10 November, Indonesia.

Stish Kumar, Y.V. and M. Mukhopdhyay, 2000. Finite Element Analysys of Ship Structure Using New Stiffened Plate Element. India: Indian Institute of Technology Starches. J. Food Res., 2: 36-48. DOI: $10.5539 /$ jfr.v2n2p36

Watson, D., 1998. Practical Ship Design. Vol.1, Elsevier Science Ltd., Kidlington, Oxford, UK. 